\title{
B-type natriuretic peptide single nucleotide polymorphism rs 198389 and survival in the general community
} Guido Boerrigter*1, Lisa C Costello-Boerrigter ${ }^{1}$, Syed Ameenuddin ${ }^{1}$, Douglas W Mahoney ${ }^{3}$, Joshua P Slusser ${ }^{4}$, Denise M Heublein ${ }^{1}$, Margaret M Redfield ${ }^{1}$, Richard J Rodeheffer ${ }^{2}$, Timothy M Olson ${ }^{5}$ and John C Burnett ${ }^{1}$

\begin{abstract}
Address: ${ }^{1}$ Cardiorenal Research Laboratory and Division of Cardiovascular Diseases, Mayo Clinic and Mayo Clinic College of Medicine, Rochester, Minnesota, USA, ${ }^{2}$ Division of Cardiovascular Diseases, Mayo Clinic and Mayo Clinic College of Medicine, Rochester, Minnesota, USA, ${ }^{3}$ Division of Epidemiology, Mayo Clinic and Mayo Clinic College of Medicine, Rochester, Minnesota, USA, ${ }^{4}$ Division of Biostatistics, Mayo Clinic and Mayo Clinic College of Medicine, Rochester, Minnesota, USA and ${ }^{5}$ Department of Pediatric and Adolescent Medicine, Division of Pediatric Cardiology, Mayo Clinic and Mayo Clinic College of Medicine, Rochester, Minnesota, USA
\end{abstract}

Email: Guido Boerrigter* - boerrigter.guido@mayo.edu

* Corresponding author

from 4th International Conference of cGMP Generators, Effectors and Therapeutic Implications

Regensburg, Germany. 19-21 June 2009

Published: II August 2009

BMC Pharmacology 2009, 9(SuppI I):P4 doi:I0.I I86/I47I-22I 0-9-SI-P4

This abstract is available from: http://www.biomedcentral.com/I47I-22I0/9/SI/P4

(c) 2009 Boerrigter et al; licensee BioMed Central Ltd.

\section{Background}

B-type natriuretic peptide (BNP) is a pleiotropic hormone with important vasodilating, natriuretic, and antifibrotic actions in the cardiovascular (CV) system. Recently it has been shown that genetic variation affects BNP levels and blood pressure $[1,2]$. We have demonstrated in a large US general population cohort that the functional single nucleotide polymorphism rs198389 in the promoter region of the $\mathrm{BNP}$ gene is common and is associated with higher BNP levels and certain clinical phenotypes [Costello-Boerrigter, L. C. et al.. in review]. he impact of congenitally elevated BNP levels on survival in the general population or in subjects with cardiovascular disease is unknown. The goal of this study was to determine the impact of rs198389 on survival in a general US population and in populations with specific CV diseases.

\section{Methods}

A random sample of the general population ( $\geq 45$ years; $n$ = 1970) from Olmsted County, $\mathrm{MN}$, was clinically characterized (including echocardiogram), genotyped for rs198389, and followed for mortality (median length of follow-up: 5.6 years). Kaplan-Meier curves were generated for genotypes using a dominant model (i.e. TT vs. TC+CC) for all subjects combined and specific population subgroups.

\section{Results}

Genotype frequencies were in Hardy-Weinberg equilibrium ( $\mathrm{p}=0.98$ ): TT $32.7 \%$, TC $49.9 \%$, and CC $17.3 \%$. Survival in the total population was not different between genotypes $(\mathrm{p}=0.98)$. The same was true for subgroups with hypertension $(\mathrm{p}=0.20)$, coronary artery disease $(\mathrm{p}=$ $0.51)$, history of myocardial infarction $(\mathrm{p}=0.36)$, left ventricular ejection fraction $\leq 50 \%(\mathrm{p}=0.36)$ or $\leq 40 \%(\mathrm{p}=$ 0.68). In contrast, C-alleles were associated with better survival in patients classified as having moderate to severe diastolic dysfunction ( $\mathrm{p}=0.02)$ and tended to have a better survival in patients with type 2 diabetes mellitus $(\mathrm{p}=$ $0.065)$.

\section{Conclusion}

Congenitally elevated BNP levels due to rs198389 did not affect survival in the general population and in several categories of CV disease but were associated with better outcome in subjects with moderate to severe diastolic 
dysfunction. This also tended to be the case in subjects with type 2 diabetes mellitus. Thus, the BNP genetic variant rs198389 does not affect survival in general but may affect outcome in specific diseases. These findings require confirmation in other populations.

\section{References}

I. Meirhaeghe A, Sandhu MS, McCarthy MI, de Groote P, Cottel D, Arveiler D, Ferrières J, Groves CJ, Hattersley AT, Hitman GA, Walker M, Wareham NJ, Amouyel P: Association between the T38 IC polymorphism of the brain natriuretic peptide gene and risk of type 2 diabetes in human populations. Hum Mol Genet 2007, 16:1343-1350.

2. Newton-Cheh C, Larson MG, Vasan RS, Levy D, Bloch KD, Surti A, Guiducci C, Kathiresan S, Benjamin EJ, Struck J, Morgenthaler NG, Bergmann A, Blankenberg S, Kee F, Nilsson P, Yin X, Peltonen L, Vartiainen E, Salomaa V, Hirschhorn JN, Melander O, Wang TJ: Association of common variants in NPPA and NPPB with circulating natriuretic peptides and blood pressure. Nat Genet 2009, $41: 348-353$.

Publish with Bio Med Central and every scientist can read your work free of charge

"BioMed Central will be the most significant development for disseminating the results of biomedical research in our lifetime. "

Sir Paul Nurse, Cancer Research UK

Your research papers will be:

- available free of charge to the entire biomedical community

- peer reviewed and published immediately upon acceptance

- cited in PubMed and archived on PubMed Central

- yours - you keep the copyright

Submit your manuscript here:

http://www.biomedcentral.com/info/publishing_adv.asp 